\section{Química em Tempo Real}

Usando o hashtag \#RealTimeChem, esta conta do Twitter, criada em 2012, reúne uma enorme comunidade de químicos. Em todo o mundo, e a qualquer hora do dia, existem milhares de químicos a partilhar o que estão a observar naquele preciso momento, partilhando em tempo real as suas experiências seja no laboratório, no escritório ou numa conferência!

Sendo um fórum público, a informação flui de forma espontânea, mostrando não só a química que se está a fazer, mas também quem a está a fazer. Em maio de 2021 existiam 70 mil tweets contendo o hashtag \#RealTimeChem e a conta @RealTimeChem tinha mais de 17 mil seguidores. Entrem nesta comunidade e comecem a partilhar a vossa química agora!

Veja mais em twitter.com/realtimechem.

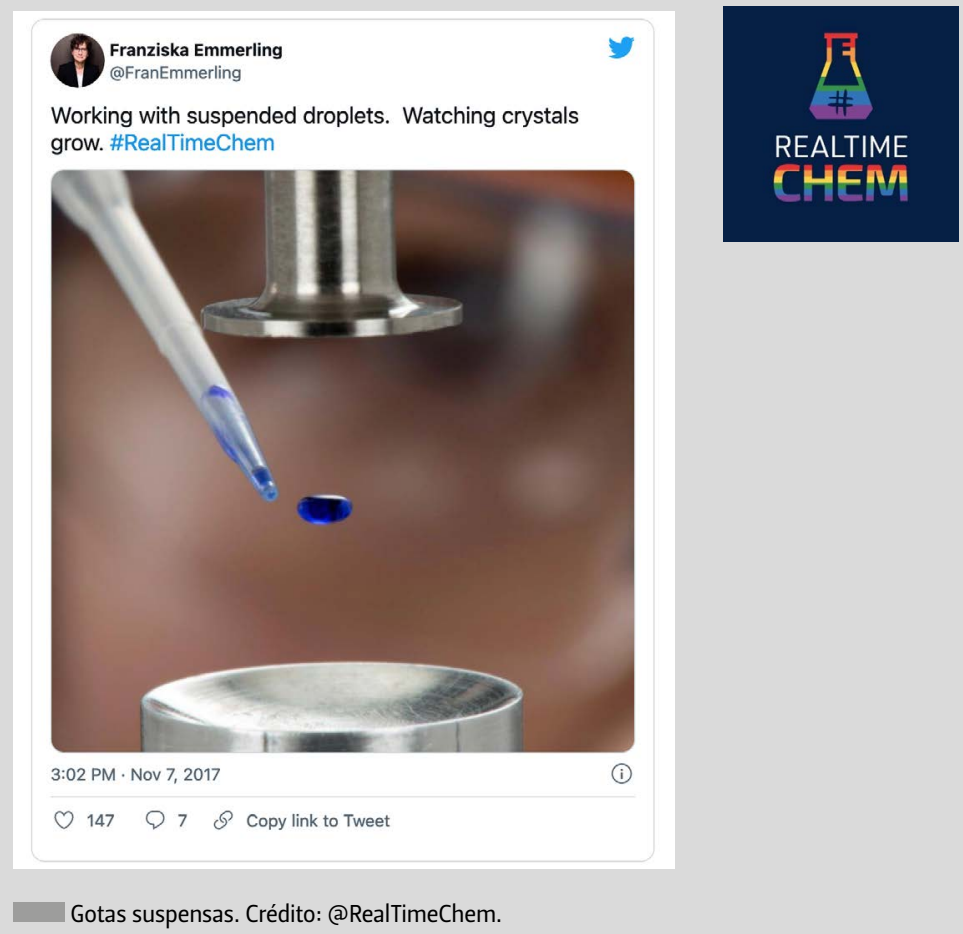

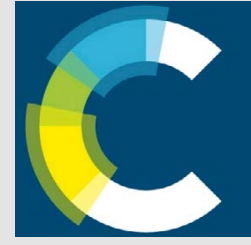

0 TikTok também já conquistou os químicos. A plataforma preferida dos adolescentes foi escolhida pela Royal Society of Chemistry para divulgar a química entre os mais novos. A conta, criada em outubro de 2020, já tem mais de 16 mil seguidores e tem algumas dezenas de vídeos que abordam temas muitos diversos. Porque são tão picantes as malaguetas? E como podemos fazer desparecer o sabor picante na boca se (corajosamente) comermos uma? Porque é que os cães molhados têm um cheiro estranho? Porque é que as cores brilhantes atraem os insetos? Descubram a resposta a estas e outras perguntas intrigantes. A química explica tudo...

Veja mais em tiktok.com/@royalsocietyofchemistry.

Vasco Bonifácio

vasco.bonifacio@tecnico.ulisboa.pt 